\title{
Research on Risk Assessment and Regionalization of Forest and Grassland Fires
}

\author{
Xinghua Li \\ The Centre of Inner Mongolia Ecology and Agricultural Meteorology, Huhhot 010051, China \\ Wenjie Wu
}

The Centre of the Command Attemper about preventing fire in Inner Mongolia forest grassland, Huhhot 010019, China

Dibo Lv, Cunhou Zhang

The Centre of Inner Mongolia Ecology and Agricultural Meteorology, Huhhot 010051, China

Received 27 July 2011

Accepted 12 March 2012

\begin{abstract}
The hazard risk and disaster degree of damage was confirmed about the forest and grassland fire in Inner Mongolia by the occurrence rule of fires, distribution of high temperature points, characteristic of distribution of vegetation types, and the extent of road coverage. Production of risk assessment and regionalization of forest and grassland fires was made by CIS, risk of fires in forest and grassland is classified as safe zones, warning zones, general risk zones, moderate risk zones and high risk zones. On the basis of conclusions of risk regionalization, forest and grassland fires will be subdivided into non-defense zones, the general defense zones, the strengthening defense zones, the key zones and the special defense zones.
\end{abstract}

Keywords: Forest and grassland fires, Risk assessment, Risk regionalization, GIS, Fire-fighting

\section{森林草原火灾风险评估及区划研究 ${ }^{*}$}

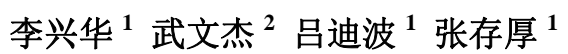 \\ 1. 内蒙古生态与农业气象中心, 呼和浩特 010051
}

2. 内蒙古森林草原防火协调调度中心，呼和浩特 010020

\begin{abstract}
摘要：通过对内蒙古森林草原火灾发生规律，高温点分布状况，植被类型分布特征，道路交通覆盖程度等 综合评估，确定内蒙古森林草原火灾致灾过程的危险性和受灾损害程度; 利用 GIS 制作森林草原火灾风险 评估和区划, 将森林草原火灾风险划分为安全区、警戒区、一般危险区、中度危险区和高度危险区; 根据 风险区划结论, 将森林草原火灾区划分为非防御区、一般防御区、加强防御区、重点防御区和特别防御区。
\end{abstract}

关键词：森林草原火灾，风险评估，风险区划，GIS，火灾防御

基金项目：内蒙古自治区科技攻关项目 “内蒙古森林草原火灾预警和评估研究” (20070501); 内蒙古气象局科技创新项目 “精细化森林草原火险等级 气象预报技术” ( nmgqxjcx201004) 资助

作者简介: 李兴华 (1971 ), 男, 高级工程师, 主要从事气候变化、生态学、森林草原火灾、气象灾害评估方法、遥感应用等研究。

E-mai1:1xh101900@163.com 


\section{1. 引言}

森林草原火灾风险是指森林或草原主体发生火 灾的程度和可能性, 表现为在特定时空环境中, 森林 或草原受火灾威胁的可能性 ${ }^{[1]}$ 。一般火灾强度越大, 频次越高，火灾所造成的破坏损失越严重，火灾的风 险也越大 ${ }^{[2]}$ 。一个区域面临何种火灾风险水平, 要采 取何种应对措施, 是森林草原火灾风险决策需要考虑 的核心问题 ${ }^{[3]}$ 。全球每年发生森林、草原火灾几十万 次; 尤其近年来森林火灾发生的频率和规模更加反 常, 已远远超过自然界的自我调节范畴, 对人类、环 境和经济所造成的危害也超过了历年。我国每年发生 森林、草原火灾上万次, 燃烧面积几十万公顷。内蒙 古历来是森林、草原火灾的高发区之一，尤其每年的 春秋两季, 火灾发生更加频繁 ${ }^{[4]}$ 。据统计1949 2000 年, 内蒙古年均发生森林火灾92.1次, 年均森林受害 面积 23.6 万 $\mathrm{hm}^{2}$; 年均发生草原火灾 138.4 次, 年均草 原受害面积 1566 万 $\mathrm{hm}^{2}{ }^{[5]}$ 。内蒙古森林草原火灾 2000 年以前呈下降趋势 ${ }^{[6]}$; 2000年后森林草原火灾逐年增 加, 从1999年62次增加到2004年311次，2005 2007 年每年都在 160 次以上。因此, 加强内蒙古森林草原 火灾风险区划, 确定防火区域, 才能更好的做好森林 草原火灾的防御。

森林草原火灾风险评估是对致灾风险、脆弱性和 承灾体的综合评估。森林草原火灾风险的环境因子包 括森林草原主体所处空间的气候、立地条件、植被类 型以及人类活动等, 森林草原火灾风险在时间上表现 为不同时间的风险不同，在空间上表现为不同水平和 垂直梯度上风险不同 ${ }^{[7-8]}$ 。过去对森林草原火灾研究大 多以火行为和火险等级预报研究为主, 少数对森林草 原火灾风险的研究也主要是以可燃物状态等单因素 进行风险评价 ${ }^{[9]}$ 和利用历史资料进行起火概率与损失 变化计算, 由于森林草原火灾受多种因素的制约, 诸 如可燃物、天气条件、地形、人类活动等, 因此这种 用单一方法进行的火灾风险区划, 很难真实反应森林 草原火灾风险状况。
因此, 本文以内蒙古火灾历史资料为基础, 利用 地理信息系统, 结合内蒙古森林草原区气候特点, 森 林草原火灾发生的规律、严重程度、植被分布特征, 卫星监测的高温点分布状况, 人类活动等开展森林草 原火灾风险评估和区划研究。对防火部门加强春秋防 火管理，有效控制火源，开辟防火道，制定防火和灭 火预案, 提高防火能力具有重要意义。

\section{2. 研究区域和数据来源及方法}

\section{1. 研究区域概况}

\section{1. 1. 内蒙古地理概况}

内蒙古自治区地处祖国北部边疆, 东与黑龙江、 吉林、辽宁三省接壤, 南与河北、山西、陕西、宁夏 相连, 西与甘肃为邻, 北与蒙古、俄罗斯两国交界, 东西长约 $2500 \mathrm{~km}$, 南北宽约 $1700 \mathrm{~km}$, 总土地面积为 118.3 万 $\mathrm{km}^{2}$, 呈狭长弧形由东北向西南方向延伸。境 内从东北向西南以大兴安岭、燕山、阴山、贺兰山、 龙首山、北山横贯全区，山地以北主要是内蒙古草原 牧业区, 山地以南主要以丘陵、山地和平原为主, 境 内镶嵌分布着 $68.2 \times 10^{4} \mathrm{~km}^{2}$ 的天然草场, $23.7 \times 10^{4}$ $\mathrm{km}^{2}$ 的森林, $7.1 \times 10^{4} \mathrm{~km}^{2}$ 耕地, 五大沙漠和五大沙地。

\section{1.2. 内蒙古森林草原资源分布概况}

受地貌、气候、土壤等自然因素影响, 内蒙古森 林草原的水平分布自东北向西南地带性明显, 分别为 森林、草甸草原、典型草原、荒漠草原、沙漠化草原 和荒漠。内蒙古森林总面积约 $2366.4 \times 10^{4} \mathrm{hm}^{2}$, 森林 覆盖率达 $20.0 \%$, 高于全国 $18.0 \%$ 的水平 ${ }^{[10]}$ 。森林总 蓄积量 $13.6 \times 10^{8} \mathrm{~m}^{3}$ 。树木种类繁多, 全区乔灌树种 达 350多种, 既有寿命长、材质坚硬的优良用材林树 种, 又有耐早耐风沙运作防护林的树种, 还有经济树 种和列入国家保护的珍贵树种。内蒙古自治区拥有呼 伦贝尔市东北部原始林区、锡林郭勒盟东北部和兴安 盟阿尔山原始林区、大青山原始林区、贺兰山原始林 区等六大原始林区，原始林区面积达到 $18.7 \times 10^{4} \mathrm{~km}^{2}$, 
居全国第二位，尤其呼伦贝尔市北部和阿尔山的樟子 松等珍贵树种保持着原始森林的特征, 是区域环境变 化的敏感地带。另外呼伦贝尔市北部和阿尔山又具有 不同的气候变化特征, 阿尔山林区是草典草原包围下 的林区, 呼伦贝尔市北部是中国北方原始林区覆盖 区，而贺兰山原始林区被沙漠包围。人工林是内蒙古 森林中不可缺少的组成部分, 不仅在条件较好的平原 区开展造林, 而且深入河区、水土流失区及牧区进行 造林。防护林、用材林、经济林、薪炭林等都发展较 快。

草原是我国国土的主体和陆地生态系统的主体, 是畜牧业发展的重要物质基础和农牧民赖以生存的 基本生产资料。我国有天然草原面积 $3.93 \times 10^{8} \mathrm{hm}^{2}$, 约占国土总面积的 $41.7 \%$, 仅次于澳大利亚, 居世界 第二位。内蒙古天然草场面积辽阔, 是国内重要的畜 牧业生产基地, 草原总面积达 $8666.7 \times 10^{4} \mathrm{hm}^{2}$, 其中 可利用草场面积达 $6818.0 \times 10^{4} \mathrm{hm}^{2[10]}$ 。内蒙古草原类 型分布多样，气候干燥、枯草期长，草原火灾频繁发 生, 给畜牧业生产、人民生活及草地生态系统带来巨 大损失，严重地制约和影响了牧区经济可持续发展。

\subsection{3. 内蒙古气候概况}

内蒙古自治区地处中纬度地带, 基座占据中温 带, 东西狭长, 地域辽阔, 气候资源丰富多变, 属于 温带大陆性气候。气候特点是气温自东北向西南逐渐 增加, 在 $-4 \sim 8^{\circ} \mathrm{C}$ 之间变化, 气温日较差平均 $12 \sim$ $16^{\circ} \mathrm{C}$; 全区无霜期 $100 \sim 140$ 天之间，呼伦贝尔市东 北部只有 $60 \sim 80$ 天。日照时间长，大部地区年日照 时数在 2700 小时以上。降水量集中于夏季, 夏季降 水量占全年降水量的 $60 \% \sim 75 \%$, 雨热同期, 比较适合 植物生长; 春季干旱少雨, 多大风和沙尘暴; 秋季温 度急剧下降, 昼夜温差大, 时常有霜冻发生; 冬季漫 长、严寒干燥 ${ }^{[1]}$ 。

\section{2. 数据资料来源}

森林草原火灾资料选 1981 2007 年, 由内蒙古 森林草原防火信息中心提供 ${ }^{[5]}$; 高温点资料采用 2000 2009 年极轨气象卫星（NOAA 系列和 FY 系列） 遥感监测的高温点记录资料; 地理信息数据采用国家 测绘局编制的 1: 25 万地形图, 内容包括 2005 年土 地利用和植被覆盖信息 ${ }^{[12]}$; 公路和铁路交通里程利用 2009 年最新统计数据 ${ }^{[10]}$ 。

\section{3. 研究方法}

通过对内蒙古森林草原火灾、植被类型分布特征 和气象条件的统计分析, 研究森林草原火灾发生的特 点和规律; 以相关分析和聚类分析为基础, 分析影响 森林草原火灾发生的主要因子, 确定森林草原火灾致 灾过程的危险性和受灾损害程度，根据森林草原火灾 发生不同时间的严重程度和火灾成因，制作森林草原 火灾风险时段评估和区划。采用因子加权叠置法 ${ }^{[13]}$, 依据森林草原火灾空间分布特征，高温点的分布状 况，植被类型分布特征，铁路和公路交通覆盖程度确 定危险等级，根据危险等级划分防治区域。

因子加权叠置法主要是充分利用 GIS (地理信息系 统）能够对地理数据进行采集、管理、查询、计算、 分析与可视化表现的功能, 在统一地理坐标基础上对 各因子指数绘图, 通过指数计算和图层叠加 ${ }^{[11]}$, 绘制 内蒙古森林草原火灾风险区划图。具体方法见技术流 程图 1。

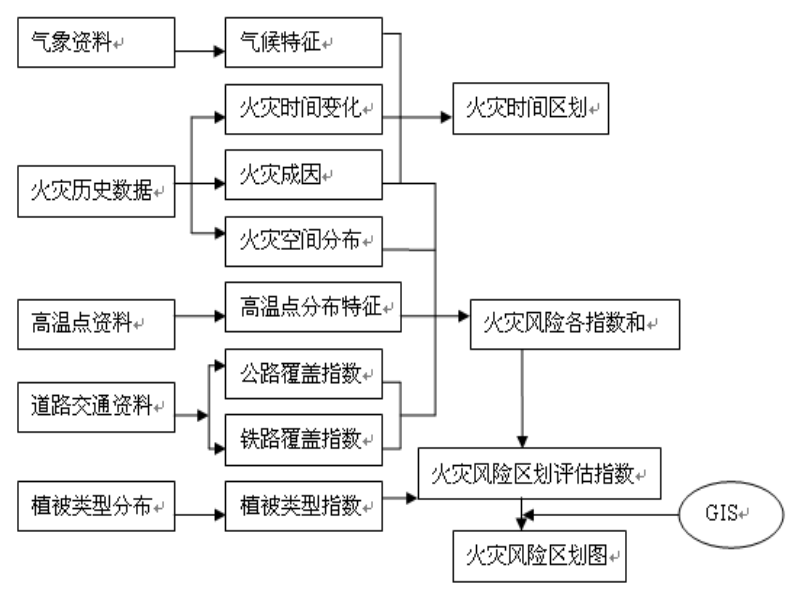

图 1 内蒙古火灾风险区划技术流程图 


\section{3. 森林草原火灾风险评估和区划内容}

\section{1. 森林草原火灾风险时段评估和区划}

内蒙古森林草原火灾的时间格局与季、月和日的 气象条件息息相关。

研究表明, 降水量与森林草原火灾发生次数的相 关系数为 -0.19 , 当日降水量大于 $10 \mathrm{~mm}$ 时, 24 小时内 无火灾发生, 48 小时内发生火灾数占样本数的 $2 \%$; 日降水量 5 10mm 时, 当日无火灾发生, 24 小时发生 火灾数占样本数的 $2 \%, 48$ 小时发生火灾数占样本数 的 $6.6 \%$; 日降水量小于 $5 \mathrm{~mm}$ 时, 火灾发生次数逐渐 增多, 其中 24 小时内发生火灾数占样本数的 $23 \%$ 。另 外, 冬季积雪也与火灾密切相关, 当积雪深度大于 $3 \mathrm{~cm}$ 并可以座住时，基本无火灾发生 ${ }^{[14]}$ 。

月平均气温在一定区间内与森林草原火灾呈正 相关, 相关系数为 0.27 ; 当最高气温低于 $-11^{\circ} \mathrm{C}$ 时, 由于积雪和人类的活动减少，一般不会发生火灾; 当 日最高气温大于 $20^{\circ} \mathrm{C}$ 时, 由于草木生长旺盛, 降水季 节性增多，也不易发生火灾; 日平均气温在-9.5 17. $7^{\circ} \mathrm{C}$ 之间时, 由于此时为春种秋收的季节, 草木含 水量小, 植被干枯, 是火灾发生的高峰期 ${ }^{[14]}$ 。

相对湿度与森林草原火灾的相关系数为 $-0.88^{* * *}$, 即湿度越大火灾发生次数越少; 湿度越小火灾发生的 次数越多。当空气中的相对湿度大于 $62 \%$ 时, 基本无 火灾发生; 相对湿度在 52 62\%之间时，火灾发生的 次数也较少; 相对湿度在 35 52\%之间时火灾发生的 次数最多 ${ }^{[14]}$ 。

风速与森林草原火灾的相关系数为 $0.86^{* *}$ 。风可 以加速地被物的水分蒸发, 加快干化; 风对火灾具有 助燃作用, 能把燃着物及余烬带到新的可燃物上, 使 火灾蔓延扩散。统计表明, 在火灾发生当日, 最大风 速大于 $7 \mathrm{~m} / \mathrm{s}$ 的机率为 $78.3 \%$, 风大使火莫延加速, 使 火场的氧气得到补充, 加剧燃烧 ${ }^{[14]}$ 。

内蒙古近 27 年总计发生森林草原火灾 5598 次,
平均每年 207.3 次。内蒙古森林草原火灾次数冬季 （12 2 月）最少，占全年火灾总数的 $0.98 \%$; 春季 (3〜 5 月) 火灾次数最多, 占全年火灾总数的 $66.1 \%$; 夏季（6８月）火灾次数较少; 秋季（9１1月）火 灾次数次多，占全年火灾总数的 $19.1 \%$ 。依据火灾发 生次数将每年 4 月和 5 月划分为极度危险期，6月和 10 月划分为高度危险期, 3 月划分为中度危险期， 9 月和 11 月划分为一般危险期， $7 、 8$ 和 2 月划分为林 火警戒期, 1 月和 12 月为安全期。从气候条件来看, 春季降水少, 气温回升快, 大风日数多, 地被物干燥, 极容易发生火灾; 秋季降水减少，地被物干枯，气温 下降快, 昼夜温差大, 人们早晚野外用火增加, 容易 引发火灾; 冬季地被物被积雪覆盖, 可燃物覆盖度和 连续度降低, 人为火源减少, 不易发生火灾 ${ }^{[2]}$; 夏季 随着雨季的来临, 植被返青, 空气湿度增大, 可燃物 燃烧性能降低，不易发生火灾，但 2000 年以后夏旱 频繁，雷击火灾次数明显增加。

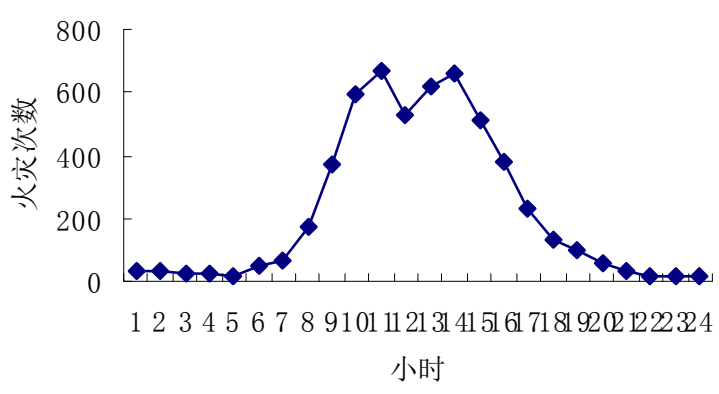

图 2 内蒙古森林草原火灾的日变化图

由图 2 可知, 每日 8 19 时是火灾的危险期, 其 中 $10 \sim 15$ 时是火灾的极度危险期; $8 \sim 9$ 时和 $16 \sim 17$ 时火灾的高度危险期; $18 \sim 19$ 时火灾的中度危险期; 6 7 时和 20 21 时是火灾的警戒期; 22 时 次日 5 时是火灾的相对安全期区。火灾的日变化与人们的生 产生活用火和气候条件息息相关, 12 时前后是午饭时 间, 也是每日温度最高、相对湿度最小、风速较大、 蒸发力较强的时期, 地表可燃物很快变干, 在加上局 地对流增强，着火容易蔓延 ${ }^{[15]} ; 22$ 时 次日 5 时是人 
类活动最少的时期, 也是气候最湿润的时期, 因此火 灾次数最少。

\section{2. 森林草原火灾空间风险评估和区划}

森林草原火灾的发生必须具备可燃物、火源和可 燃烧气象条件才能发生火灾 ${ }^{[16]}$, 因此森林草原火灾空 间风险评估和区划必需充分考虑这些因子。火灾风险 评估是对致灾风险、脆弱性和承灾体的综合评估 ${ }^{[17]}$ 。 致灾风险评价主要是分析火灾发生的起因, 根据孕灾 环境建立自然、人为和境外入侵的评价因素, 结合历 年火灾数据统计起火频率, 即火灾致灾风险。脆弱性 评价对承灾体以及周围孕灾环境进行综合评价, 利用 历年火灾数据分布规律，结合孕灾环境评价火灾发 生区域火灾蔓延的可能性。承灾体分为自然承灾体和 社会承灾体 ${ }^{[1]}$, 自然承灾体评价主要是对可能发生火 灾区域的植被生物量进行评估, 社会承灾体主要是对 人类社会和生物界造成的影响评估。

\subsection{1. 森林草原火灾可燃物类型分布}

内蒙古森林草原区地面植被的分布决定了火灾 次数空间分布呈东多西少走势 ${ }^{[2]}$ 。由内蒙古植被分布 状况可知, 呼伦贝尔市北部原始林区，人为火源少， 主要以雷击火灾为主; 呼伦贝尔市东部为原始林区、 高覆盖度草甸草原区和农林交错区, 植被连续度好, 人口较多, 起火原因复杂, 是森林草原火灾高发区; 呼伦贝尔市南部和兴安盟的植被类型为农林交错区, 人员活动频繁, 火源增加, 发生火灾次数最多; 呼伦 贝尔市西部和锡盟东北部的植被类型为草甸草原, 由 于本区生产以畜牧为主, 人员活动相对较少, 火灾发 生的次数略少; 通辽市北部、赤峰市北部、锡盟中部 和鄂尔多斯市东部为典型草原分布区, 由于牧草高 度、盖度和连续度受降水的影响较大, 火灾次数明显 下降; 锡盟西部、乌兰察布市北部、包头市、鄂尔多 斯市中西部的植被类型为荒漠化草原, 植被长势较 差, 不易发生火灾; 阿拉善盟大部为荒漠, 植被稀疏,
人烟稀少，基本无火灾发生。

\subsection{2. 森林草原火灾空间分布}

内蒙古近 27 年总计发生森林草原火灾 5598 次, 平均每年 207.3 次。由图 3 可知, 内蒙古森林草原火 灾空间分布呈东多西少。呼伦贝尔市是火灾的高发 区, 其中鄂伦春旗年平均火灾次数最多为 33.7 次, 其次牙克石市和莫力达瓦旗年平均火灾次数为 13 14 次, 都属高度危险区; 呼伦贝尔市西部和南部、兴 安盟北部和锡林郭勒盟东北部年平均火灾次数为 5 9 次, 属中度危险区; 满洲里市、兴安盟大部、通辽 市北部、赤峰市北部和锡林郭勒盟中部年平均火灾次 数为 $2 \sim 5$ 次, 属一般危险区; 通辽市南部、赤峰市 南部、锡林郭勒盟西南部、鄂尔多斯市东部年平均火 灾次数为 1 2 次, 属警戒区; 其他地区的年平均火 灾次数在 1 次以下, 植被稀疏, 属安全区。

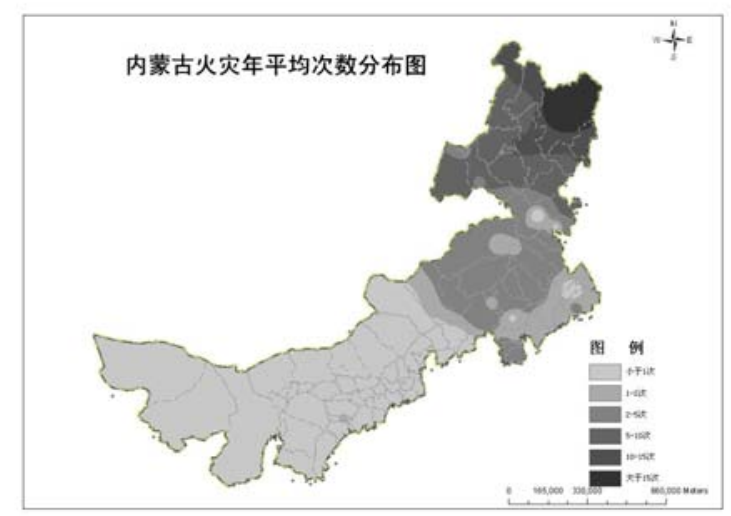

图 3 内蒙古森林草原火灾年平均次数分布图

\section{2. 3. 森林草原高温点空间分布}

通过对内蒙古 2000 2009 年卫星遥感监测的高 温火点资料统计, 内蒙古近 10 年高温火点平均每年 595.3 次。由图 4 可知, 呼伦贝尔市是高温火点密集 区, 年平均 15 次以上, 属高度危险区, 其中鄂伦春 旗年平均高温火点最多为 157.4 次, 其次额尔古纳市、 莫力达瓦旗、牙克石、阿荣旗、扎兰屯、陈旗年高温 火点次数为 $30 \sim 71.3$ 次; 兴安盟北部和锡林郭勒盟 东北部的高温火点次数为 $10 \sim 15$ 次, 也属高度危险 区; 兴安盟南部、锡林郭勒盟中部年高温火点次数为 
5 10 次, 属中度危险区; 通辽市北部、锡林郭勒盟 西南部年高温火点次数为 $2 \sim 5$ 次, 属一般危险区; 通辽市大部、赤峰市北部、锡林郭勒盟西部年高温火 点次数为 $1 \sim 2$ 次, 属警戒区; 其他地区年高温火点 次数都在 1 次以下, 植被稀疏, 属安全区。另外, 通 过叠加道路交通图发现, 高温点在主要的交通干线周 围也是密集区。

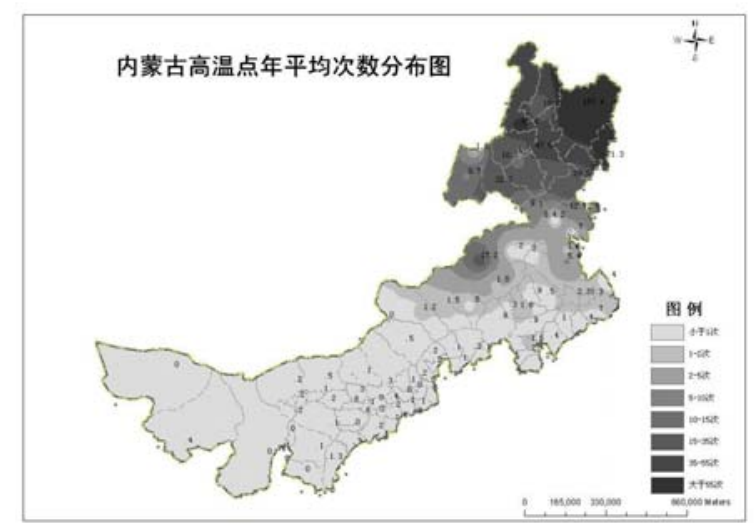

图 4 内蒙古森林草原高温点年平均次数分布图

\section{2. 4. 森林草原火灾成因分析}

由图 5 可知, 发生火灾后不能查明原因的占火灾 总数的 $33 \%$ 。人为引发火灾次数占火灾总数的 $61 \%$, 其中吸烟引起火灾占火灾总数的 $19 \%$; 机动车失火引 起火灾占火灾总数的 $12 \%$; 上坟烧纸引起火灾占火灾 总数的 $7 \%$; 烧茬地引起火灾占火灾总数的 $6 \%$; 人为 放火引起火灾占火灾总数的 $4 \%$; 其他原因引起火灾 占火灾总数的 $13 \%$ 。雷击引起火灾占火灾总数的 $6 \%$ 。

吸烟和机车失火是人为引发森林草原火灾的最 主要原因, 尤其每年的 4、5 和 10 月份是本区的春耕 和秋收的主要时期, 野外人员活动和车辆使用频繁, 极易引发火灾。另外上坟烧纸虽然只占火灾总数的 $7 \%$ ，但是其引发的火灾集中在每年清明前后，这类火 灾经过加强管理, 最近几年已经基本杜绝。雷击火是 由于天气干燥, 干雷暴引发的火灾; 雷击火灾由于受 天气系统的影响, 起火时上空有云覆盖, 卫星遥感发
现时, 火灾已经扩散开来, 因此雷击火灾具有随机性 大, 人为控制难的特点; 预防雷击火的基本原则为早 发现早扑救, 严防火灾蔓延 ${ }^{[18]}$; 雷击火发生的主要区 域为呼伦贝尔市东北部和锡盟东北部, 主要发生时期 为每年的 5 月下旬 $\sim 6$ 月底、 9 月下旬 $\sim 10$ 月上旬也 有少量的雷击火发生; 其中 $2000 \sim 2005$ 年共发生雷 击火 187 次,年均 31 次, 比 1981 2000 年均值 (9 次) 增多了 23 次, 其中 2004 年最多达到 55 次。

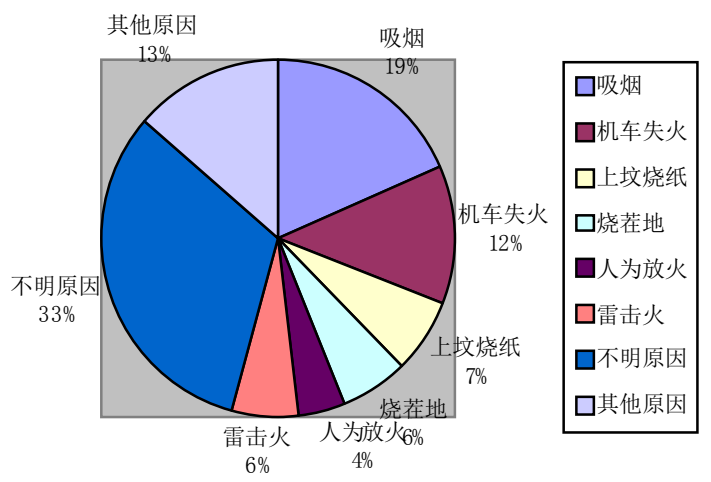

图 5 内蒙古森林草原火灾成因分布图

\section{2. 5. 森林草原火灾空间风险评估和区划}

\subsubsection{1 森林草原火灾空间风险评估模型}

根据森林草原火灾发生的严重程度，高温点的分 布状况，植被类型分布特征等区划结论通过综合评 估, 制作内蒙古森林草原火灾风险评估和区划。另外, 由于机车失火、拖拉机喷火和吸烟都是火灾发生的重 要原因, 而这些火灾的发生又与道路交通密切相关, 因此将道路交通覆盖程度也作为一个评判指标, 并按 道路交通覆盖指数（道路交通覆盖指数 $=$ 公路（铁路） 长度/总面积）确定危险等级。而气候干燥度因子在 风险区划中只做月季危险度指标，在空间上湿度越大 的地区植被覆盖好, 火灾发生的次数多, 干燥度越大 的地区，植被稀疏，不易发生火灾，因此气候因子不 作为空间区划的指标。通过表 1 中多指标因子的加权 综合评价, 确定森林草原火灾风险评价指标, 并根据 指标大小划分危险等级，绘制内蒙古森林草原火灾风 险区划图。 
火灾风险评估指数 $=\mathrm{f}$ （火灾孕灾环境，致灾因 子，承灾体） ${ }^{[1]}$

其中火灾孕灾环境包括森林草原火灾的历史次 数, 卫星遥感监测高温火点次数, 道路分布; 致灾因 子包括可燃物种类和火源（人为火源、雷击火灾、自 然火灾、机车失火、境外烧入等) ${ }^{[19]}$; 火灾承灾体主 要是森林和草地。由于火灾指数、高温点指数、公路 交通指数和铁路交通指数与植被之间是交叉关系, 植 被的好坏决定了火灾发生和蔓延的程度, 因此将植被
类型指数与其他指数之和做乘法处理, 具体火灾风险 评估区划模型如下:

$$
\mathrm{HZFX}=(\mathrm{A}+\mathrm{B}+\mathrm{D}+\mathrm{E}) \times \mathrm{C}
$$

其中 $\mathrm{A}$ 是历史火灾次数指数; $\mathrm{B}$ 是高温点次数指 数; $\mathrm{C}$ 是植被类型指数; $\mathrm{D}$ 是公路交通指数; $\mathrm{E}$ 是铁路 交通指数。根据各指标的重要程度, 确定火灾次数指 数权重为 $35 \%$; 高温点次数的权重为 $30 \%$; 植被类型 指数权重为 $18 \%$; 公路交通指数权重为 $9 \%$; 铁路交通 指数权重为 $8 \%$ 。火灾风险评价指标见表 1 。

表 1 火灾风险评价指数和指标一览表

\begin{tabular}{|c|c|c|c|c|c|c|c|}
\hline \multicolumn{4}{|c|}{$\begin{array}{l}\text { 风险区划因子及权重 } \\
\text { 指数 }\end{array}$} & \multicolumn{4}{|l|}{ 指 标 } \\
\hline 火灾次数 $\mathrm{p}$ & $>15$ & $11 \sim 15$ & $5 \sim 10$ & $2 \sim 5$ & $1 \sim 2$ & $\leq 1$ & \\
\hline A 指数 & 12 & 10 & 8 & 6 & 4 & 2 & \\
\hline 高温点次数 q & $>15$ & $11 \sim 15$ & $5 \sim 10$ & $2 \sim 5$ & $1 \sim 2$ & $\leq 1$ & \\
\hline B 指数 & 10 & 8 & 6 & 4 & 2 & 1 & \\
\hline 植被类型 $\mathrm{z}$ & 森林 & 草甸草原 & 典型草原 & 农田 & 沙地 & 荒漠化草原 & 荒漠 \\
\hline $\mathrm{C}$ 指数 & 6 & 5 & 4 & 3 & 2 & 1 & 0 \\
\hline 公路交通指数 $\mathrm{m}$ & $>0.5$ & $0.41 \sim 0.5$ & $0.31 \sim 0.4$ & $0.21 \sim 0.3$ & $0.11 \sim 0.2$ & $\leq 0.1$ & \\
\hline $\mathrm{D}$ 指数 & 3 & 2.5 & 2 & 1.5 & 1 & 0.5 & \\
\hline 铁路交通指数 $n$ & $>0.2$ & $0.16 \sim 0.2$ & $0.12 \sim 0.16$ & $0.08 \sim 0.12$ & $0.04 \sim 0.08$ & $\leq 0.04$ & \\
\hline $\mathrm{E}$ 指数 & 3 & 2.5 & 2 & 1.5 & 1 & 0.5 & \\
\hline
\end{tabular}

\subsubsection{2 森林草原火灾空间风险评估和区划结论}

根据森林草原火灾发生的特点和严重程度, 将森 林草原火灾风险划分为高度危险区、中度危险区、一 般危险区、安全区和警戒区 ${ }^{[20]}$, 各划分指标见表 2 。 高度危险区主要分布在呼伦贝尔市中部和东部; 中度 危险区主要分布在呼伦贝尔市中部偏西和南部、兴安 盟北部和锡林郭勒盟东北部; 一般危险区主要分布在 呼伦贝尔市西部、兴安盟大部、通辽市北部、赤峰市 北部和锡林郭勒盟中东部; 警戒区主要分布在通辽 市、赤峰市、锡林郭勒盟西部、乌兰察布市南部、呼 和浩特市、包头市南部、鄂尔多斯市北部和巴彦淖尔
市南部; 安全区主要分布在中西部植被稀疏的荒漠化 草原区或荒漠区。根据风险区划结论, 将森林草原火 灾区划分为特别防御区、重点防御区、加强防御区、 一般防御区和非防御区，具体见图 6 。

表 2 内蒙古森林草原火灾风险指数划分及预防措施表

\begin{tabular}{ccc}
\hline HZFX 指数 & 危险程度 & 预防要求 \\
\hline$\leq 10$ & 安全区 & 无需预防 \\
$11 \sim 30$ & 警戒区 & 一般预防 \\
$31 \sim 65$ & 一般危险区 & 加强预防 \\
$66 \sim 100$ & 中度危险 & 重点预防 \\
$100<$ & 高度危险 & 特别防御 \\
\hline
\end{tabular}




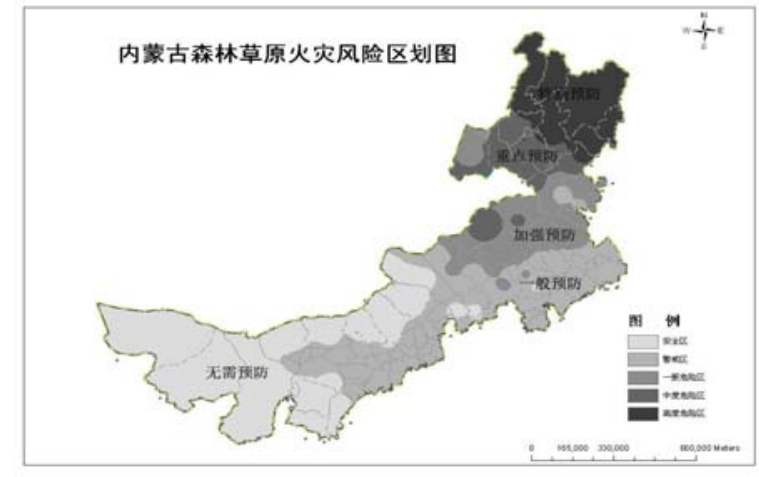

图 6 内蒙古森林草原火灾风险和防御区划图

\section{2. 6 . 森林草原火灾风险区划应用}

开展森林草原火灾时空风险区划的目的是在火 险等级预报、火灾预防和火灾扑救中应用。根据森林 草原火灾月季区划可以将春秋季做内蒙古森林草原 火灾预防的重点时段，并将每年春季 4 月、5 月和秋 季 10 月作为防火关键期; 根据火灾发生的日变化规 律和风险评估结论, 得出中午前后由于温度高、风速 大、地被物干燥, 有利于火灾蔓延, 不利于扑救, 因 此有经验的扑火指挥员, 常常利用早晚和午夜对打火 有利的气象条件, 进行包围战, 把火场围起来, 一举 歼灭 ${ }^{[15]}$ 。

火灾空间风险区划结论，是做好火险等级预报的 基础, 由于内蒙古东西跨度大, 气候和植被分布的差 异性强，在火险等级预报中单一的预报模型很难满足 预报需求。因此根据火灾空间风险区划将预报区域划 分为五个区，在不同预报区域，根据各自的植被和气 候特点, 建立不同的森林草原可燃物可燃烧等级模型 和火险气象等级预报模型, 并利用 GIS 软件绘制火险 等级预报图。

\section{4 结论与讨论}

内蒙古森林草原火灾次数在 20 世纪末曾经每年 降到100次以下; 进入 21 世纪, 森林草原火灾次数呈 逐年递增趋势, 已经从2000年的150次上升到2005年 的346次，2006年也达到200次以上。随着国家天然林 保护工程和生态建设工程的实施, 内蒙古大部地区的 植被逐年得到恢复, 在丰水年, 植被长势更好, 而许
多地区又实施围栏封育和禁牧等政策, 过高的植被得 不到及时合理的利用, 必然使这些地区的火灾隐患和 火灾次数增多; 另外随着气候变暖 ${ }^{[21-22]}$, 内蒙古东北 部林区的降水呈逐年减少趋势, 春夏秋三季的阶段性 干旱时有发生, 夏季干雷暴引发的森林火灾次数也呈 增加趋势。内蒙古森林草原火灾的分布格局也在发生 重大变化, 东部森林火灾增加, 草地火灾减少; 而中 西部地区随着植被恢复, 火灾次数呈逐年增加趋势, 历史上没有火灾发生的区域, 近几年也有火灾发生。 这使火灾的防御范围不断扩大, 防御时间不断延长, 由历史上东部区防火, 变成全区性防火, 由春秋季防 火, 变成全年性预防。因此, 本风险评估和区划适应 了当前防火工作的需要, 对防火部门有效控制火源, 科学规划开辟防火道, 制定防火和灭火预案, 提高防 扑火能力具有重要的参考价值。

\section{参考文献}

1. Fan W.C., Sun J.H., Lu S.X. and et al., Fire Risk Assessment Methodology, Beijing: Science Press, 2004. 范维登,孙金华,陆守香等, 火灾风险评估方法学 [M], 北 京: 科学出版社,2004.

2. Zhang J.Q., Liu X.P. and Tong Z.J., The study of grassland fire disaster risk assessment and regionalization: A case study in the western Jilin Province, Geographical Research, 2007, 26(4), 755-762. 张继权,刘兴朋,佟志军,草原火灾风险评价与分区一以 吉林省西部草原为例 [J],地理研究,2007,26(4),755-762.

3. Chen Y., Study on the Establishment of district Fire risk criteria, Fire Science and Technology, 2006, 25(5), 646-648.

陈也, 区域火灾风险准则的确立研究 [J],防火科学与 设计,2006,25(5),646-648.

4. Li X.H., Guo X.X. and Li S.S., The Occurrence Rule and Character of Forest and Grassland Fire in Inner Mongolia, Meteorological Monthly, Meteorology Journal of Inner Mongolia, 2003,28-30. 李兴华, 郭西峡,李树森,内蒙古自治区森林草原火灾发 生的规律及特征,内蒙古气象,2003,28-30.

5. The Centre of the Command Attempter about preventing fire in Inner Mongolia forest grassland (1981-2007). 内蒙古森林草原防火协调调度中心(1981-2007 年).

6. Li X.H., Guo X.X., Li Y.P and et al., The Evolution of Forest and Grassland Fire and the Relationship of it to Meteorological Condition in Inner Mongolia, Meteorological Monthly, 2003, 6, 15-19. 李兴华,郭西峡,李云鹏等,内蒙古森林草原火险发生的 演变规律及与气象条件关系 $[\mathrm{J}]$, 气象,2003,6,15-19. 
7. Huang C.F, Basic Principles of Risk Analysis of natural Disasters, Journal of Natural Disasters , 1999, 8 (2), 21-30.

黄崇福,自然灾害风险分析的基本原理[J],自然灾害学 报, 1999,8(2),21-30.

8. Huang H.F, Zhang J.X., Chen Z.F. and et al., Toward a new kind of natural disaster risk zoning map, Journal of Natural Disasters, 2004,12(3) , 9-15.

黄崇福,张俊香,陈志芬等,自然灾害风险区划图的一个 潜在发展方向[J],自然灾害学报,2004,12(3),9-15.

9. Liu X.P., Zhang J.Q., Zhou D.W. and et al., Study on Grassland Fire Risk Dynamic Distribution Characteristic and Management Policy,Chinese Journal of Grassland, 2006, 18(6),77-82.

刘兴朋,张继权,周道伟等,中国草原火灾风险动态分布 特征及管理对策研究 [J], 中国草地学报,2006,18(6): 77-82.

10. National Bureau of Inner Mongolia survey team, Inner Mongolia Economic and social survey Yearbook-2010, BeiJing:China Statistics Press,2010.

国家统计局内蒙古调查队,内蒙古经济社会调查年鉴 - -2010[M], 北京: 中国统计出版社,2010.

11. Wu H.B. and et al., Analysis on main meteorological disasters in the Inner Mongolia Autonomous Region, Bei jing: China Meteorological Press, 1990.

吴鸿宾等,内蒙古自治区主要气象灾害分析 $[\mathrm{M}]$, 北京: 气象出版社, 1990.

12. Tong Z.J., Zhang J.Q.,.Liao X.Y. and et al., A GIS-based research on grassland fire disaster risk management decision support system, Journal of Northeast Normal University(Natural Science Edition), 2008, 40(2),115-120.

佟志军,张继权,廖晓玉,刘兴朋,基于 GIS 的草原火灾风 险管理辅助决策支持系统的研究.东北师大学报(自然 科学版),2008,40(2),115-120.

13. Yin H.W, Kong F.H. and Li X.Z., GIS-based forest fire risk zone mapping in Daxing'an Mountains, Chinese Journal of Applied Ecology, 2005, 16(5), 833-837. 尹海伟,孔繁花,李秀珍,基于 GIS 的大兴安岭森林火险 区划,应用生态学报,2005,16(5),833-837.

14. Li X.H., Li. Y.P. and Yang L.P., Inner Mongolia forest grassland fire danger rating short term prediction method and system study. Meteorological Monthly, 2003, 6, 79-82.

李兴华,李云鹏,杨丽萍,内蒙古森林草原火险等级短期 预报方法及系统开发 [J], 气象,2003,6,79-82.

15. Zhou G.S., Lu Q. and et al., Weather and forest grassland fire. Bei Jing: China Meteorological Press. 2009.

周广胜,卢琦等, 气象与森林草原火灾 $[\mathrm{M}]$, 北京: 气象出 版社,2009.

16. Zhao F.J., Wang Y.M., Shu L.F. and et al., Progress in Studies on Influences of Climate Change on Forest Fire Regime, Advances in Climate Change Research, 2009, 5(1),50-55.

赵凤君,王玉明,舒立福等,气候变化对林火动态的影响 研究进展 $[\mathrm{J}]$, 气候变化研究进展,2009,5(1),50-55.
17. Li S. K., Huo Z.G., Wang S.Y. and et al., Risk evaluation system and models of agro meteorological disasters, Journal of Natural Disasters, 2004, 13(1), 77-87. 李世奎,霍治国,王素艳等,农业气象灾害风险评估体系 及模型研究[J],自然灾害学报,2004,13(1),77-87.

18. Li X.H., Yang L.P. and Lv D.B, The Occurrence Reason of Forest and Grassland Fire and fire risk forecast in summer of Inner Mongolia, Meteorology Journal of Inner Mongolia, 2004, 13(1), 77-87.

李兴华,杨丽萍,吕迪波,内蒙古夏季森林火灾发生原因 及火险等级预报 [J],内蒙古气象, 2004,2,27-29.

19. Zhang S.Y., Zhu C.H. and Chen Z.H., Research on forest fire meteorological environmental elements and large forest fires, Journal of Natural Disasters, 2000, 9(2),111-117.

张尚引,祝昌汉,陈正洪,森林火灾气象环境要素和重大 林火研究 [J],自然灾害学报,2000,9(2),111-117.

20. Liu X.P., Zhang J.Q. and Fan J.B., Historical data-based risk assessment of fire in grassland of northern China, Journal of Natural Disasters, 2007, 16(1),61-65. 刘兴朋,张继权,范久波,基于历史资料的中国北方草原 火灾风险评价,自然灾害学报,2007,16(1),61-65.

21. China's National Assessment Report on Climate Change of Editorial Board, China's National Assessment Report on Climate Change,Beijing: Science Press, 2007. 气候变化国家评估报告编写委员会, 气候变化国家评 估报告[M], 北京: 科学出版社,2007,7-17。

22. Ding Y.H., Ren G.Y., Shi G.Y. and et al., China's National Assessment Report on Climate Change(I): Climate Change in China and the Future trend, Advances in Climate Change Research, 2006, 2(1), 3-8. 丁一汇,任国玉,石广玉,等,气候变化国家评估报告(I): 中国气候变化的历史和未来趋势 $[\mathrm{J}]$, 气候变化研究进 展,2006,2(1),-8。 